\title{
鋼杭補強防波堤の補強効果に及ぼす杭の曲げ剛 性の影響に関する模型気中載荷試験
}

\author{
勝呂 基弘 1 - 菊池 喜昭 2 兵動 太- 3 ・山崎 佑太朗 4 ・ \\ 玉置 才哉子 4 ・森安 俊介 5 ・及川 森6 \\ 1 学生会員 東京理科大学大学院（干278-8510 千葉県野田市山崎 2641） \\ E-mail: 7614615@ed.tus.ac.jp \\ 2フェロー会員 東京理科大学 教授 理工学部土木工学科（广278-8510 千葉県野田市山崎 2641） \\ E-mail: kikuchi_y@rs.tus.ac.jp \\ 3 正会員 東京理科大学 助教 理工学部 土木工学科（下278-8510 千葉県野田市山崎 2641) \\ 4 東京理科大学 理工学部 土木工学科（干278-8510 千葉県野田市山崎 2641） \\ 5 正会員 新日鐵住金株式会社＼cjkstart鋼構造研究部( ⿳293-8511 千葉県富津市新富 20-1) \\ 6 正会員 新日鐵住金株式会社＼cjkstart建材開発技術部(广⿳100-8071 東京都千代田区丸の内 2-6-1)
}

\begin{abstract}
2011 年の東日本大震災において防波堤が津波によって被災した。そこで，ケーソン式防波堤を鋼管杭と 裏込め材で補強した構造形式が提案されている。この構造形式に用いる鋼杭の曲げ剛性の合理的設計に資 するべく，実物の $1 / 60$ のスケールで，模型気中載荷実験を行った．本研究では，鋼杭の曲げ岡性の違いに よるケーソンの補強の効果の変化を検討した。その結果，ケーソンの抵抗力の発揮には，ケーソン奥行方 向の鋼杭の全体岡性が影響することがわかった。また，鋼杭の曲げ岡性が異なることによってケーソンか ら杭に作用する荷重分布にも違いがみられることがわかった。
\end{abstract}

Key Words : tsunami, breakwater, reinforcement, steel pile, resistant behavior of ground

\section{1. はじめに}

2011 年東日本大震災を受けて，津波による沿岸部の被 害は甚大であった．特に港湾域を静穏に保つための防波 堤が多く被災しており，設計の考え方の見直しが求めら れている. 更に近い将来，高い確率で東南海・南海トラ フ地震の発生も予想されており, 既設ケーソン式防波堤 の耐津波抵抗性を高めるための補強も含めた，大津波に 対する港湾構造物のハード対策が求められている. そこ で，津波に対しても「粘り強く抵抗する」防波堤を構築 することにより，巨大津波発生時に一人でも多くの人を 守ることができるようにすることが必要である.

菊池ら ${ }^{1)}$ は, 図-1に示すように, ケーソン背面から少し 離して, 鋼管杭を打設し，それらの間に裏込めを設ける ことにより耐津波抵抗性を高める補強工法を提案した. 既往の気中載荷実験 $\left.{ }^{1}\right)$ 水理実験 ${ }^{2}$ より，本補強工法を施 すことによって，従来のケーソン式防波堤がより粘り強 い抵抗性を示すようになることが示されている. また， ケーソンと鋼杭には適切な離隔距離が必要なこと, 鋼杭 の根入れ長さは杭下端が固定されているほどには必要な いが, 根入れ長さが短かすぎると抵抗性が低下すること,
ケーソン背面地盤が洗掘されるとケーソンの抵抗性を低 下するものの補強効果は維持されることがわかっている 3). また, 水理実験の結果 ${ }^{2}$ から, 本補強工法を用いると, 越流した場合でもケーソン直下に至る洗掘を抑えること でケーソンの而津波抵抗性を増すことができることが分 かっている，ただし，越流が問題となるケースでは，杭 の背後は洗掘が生じるため, 洗掘によって杭の背後地盤 が低下することを前提に杭の根入れ等の設計をすること が必要である.

以上のような課題の前段として，本研究では，本補強 工法に用いる杭の断面の決定のための基礎資料を得るべ

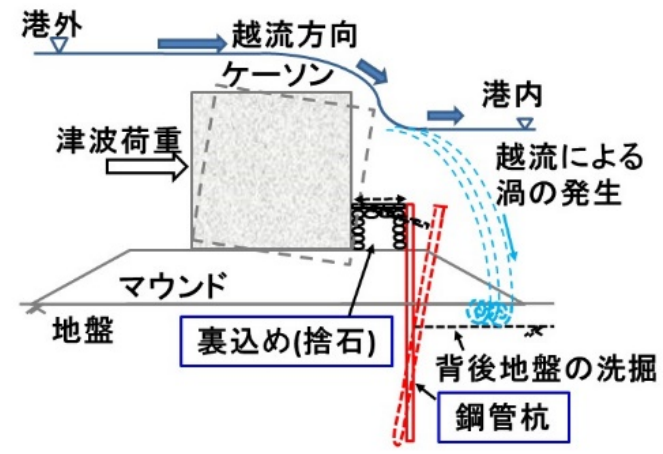

図-1＼cjkstart補強工法断面図 
く, 鋼杭の曲げ岡性の違いがケーソンの補強効果に及ぼ 寸影響について着目した, ケーソン模型の気中水平載荷 実験を行った。本実験の模型は実物のほぼ $1 / 60$ スケール を想定したものである.

\section{2. 実験概要}

本工法の適用性を検討するために，本研究では害物の 1/60 スケールを想定して模型気中水平載荷実験を実施し た. 図-2に実験のイメージを示す.

本実験は表-1 に示寸井合 ${ }^{4}$ の相似則に従い 1/60 スケー ルで設計した．土槽には $L 1580 \mathrm{~mm} \times H 800 \mathrm{~mm} \times B 400 \mathrm{~mm}$ の鋼製土槽を用いた。地盤には気乾状態の硅砂 5 号を用 い，空中落下法にて相対密度 $80 \%$ の地盤を作製した。 中 詰材には地盤と同じ硅砂 5 号を使用した。ケーソン模型 は $L 300 \mathrm{~mm} \times H 380 \mathrm{~mm} \times B 300 \mathrm{~mm}$ の矩形鋼製箱に砂と鉄球 を詰め, 重量が $752 \mathrm{~N}$ (単位体積重量 $22.0 \mathrm{kN} / \mathrm{m}^{3}$ ) となるよ うにした.このため, 模型地盤への平均接地圧は $8.4 \mathrm{kN} / \mathrm{m}^{2}$ となっている．鋼杭は実大スケールの鋼管杭 $\phi 1000 \mathrm{~mm}$ $\times t 12 \mathrm{~mm}$ を連続的に配置した場合に相当する鋼板杭 $\left(L 30 \mathrm{~mm} \times H 430 \mathrm{~mm} \times t 3.2 \mathrm{~mm}, E I=5.6 \times 10^{5} \mathrm{~N} \cdot \mathrm{mm}^{2} / \mathrm{m}\right)$ を基本 に，数種類の板厚の鋼板杭を模型杭として使用した. 根 入れ長さは既往の研究成果 ${ }^{3} に$ に基づき, $t=3.2 \mathrm{~mm}$ の杭の 場合の最適根入れ深度である $280 \mathrm{~mm}$ とした. なお，根 入れ深度は，ケーソンの初期据え付け面を基準としてい る.

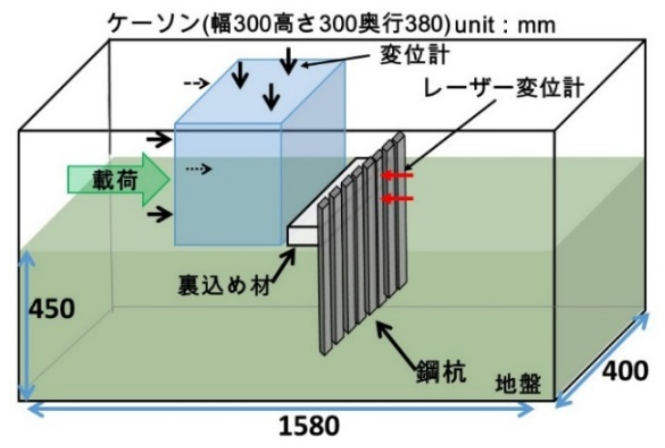

図-2 実験概要

表-1 相(以比

\begin{tabular}{c|c}
\hline 物理量 $(\lambda=60)$ & 模型/実大 \\
\hline \hline 密度 & 1 \\
地盤ひずみ & $1 / \lambda^{1 / 2}$ \\
長さ & $1 / \lambda$ \\
有効応力 & $1 / \lambda$ \\
地盤変位 & $1 / \lambda^{3 / 2}$ \\
曲げモーメント & $1 / \lambda^{3}$ \\
曲げ岡性 & $1 / \lambda^{7 / 2}$ \\
\hline
\end{tabular}

表-2 実験ケースの一覧

\begin{tabular}{|c|c|c|c|c|}
\hline \multirow{2}{*}{$\begin{array}{c}\text { 鋼杭板厚 } \\
\text { t(mm) }\end{array}$} & \multirow{2}{*}{$\begin{array}{c}\text { 杭1本あたりり } \\
\text { の曲げ剛性 } \\
\left(\mathrm{N} \cdot \mathrm{m}^{2}\right)\end{array}$} & \multicolumn{3}{|c|}{ 使用した杭の本数 } \\
\hline & & 12本 & 6本 & 3本 \\
\hline 1.0 & 0.512 & $1-12$ & - & - \\
\hline 2.3 & 6.24 & $2-12$ & $2-6$ & $2-3$ \\
\hline 3.2 & 16.8 & $3-12$ & $3-6$ & $3-3$ \\
\hline 4.0 & 32.8 & - & $4-6$ & - \\
\hline 5.1 & 68.0 & - & - & $5-3$ \\
\hline
\end{tabular}

鋼板杭に生じる曲げひずみを計測するためひずみゲージ を 10 深度(両面)に貼付した(具体的な貼付個所は後述す る). 鋼板杭とケーソンの離隔は既往の研究成果 ${ }^{3}$ に基づ き，最適離隔距離である $50 \mathrm{~mm}$ とした. 鋼板杭とケーソ ンの間には, 平均粒径 $5 \mathrm{~mm}$ の玉石を $50 \mathrm{~mm}$ の高さに積 み上げ，裏込めとした．なお，今回の実験ではマウンド はモデル化していない. これは, 本研究の主題が, ケー ソンから地盤や中詰を介して杭にどのように力が伝わる かを主眼とした実験としたためであり，マウンドが存在 することによる支持力破壊の影響を見ることを主眼とし た実験ではないからである.

なお, 本実験シリーズでは鋼杭としては鋼管杭ではなく, 板杭を用いた．板杭を用いることで，杭幅を変えずに杭 の剛性を細かく変化させることができるためである．ま た, 板杭を用いると, 鋼管杭などに比べて, 杭が降伏し にくくなる. 従って, 本研究では杭は比較的大きくたわ んでいるが，鋼杭は弾性範囲で実験に供されている.

ケーソン模型には載荷バーを介してジャッキで水平力 を作用させた. 載荷バーとケーソン模型との接触面には テフロンシートを貼ることで，また，地盤と土槽との接 触面はグリースとメンブレンを用いることで摩擦を低減 した．また，ケーソン底面には 150 号のサンドペーパー を貼付し，底面の摩擦抵抗を調整した。

実験では, 津波荷重を想定し, ケーソンの底面から 150 $\mathrm{mm}$ の高さのところを，ジャッキを用いて静的に変位速 度 $1.0 \mathrm{~mm} / \mathrm{min}$ で強制変位させた. 本来, 津波や波浪によ る荷重は分布荷重であるが，ここでは，集中荷重で載荷 した. このとき，集中荷重の作用高さは波力合力の作用 高さで代表させた．このことにより，ケーソン下面での 荷重とモーメントの関係は分布荷重と同じ条件となって いる. 水平荷重を受けた場合，主としてケーソン下面か ら地盤に力が伝わるため, ケーソン下面で等価な荷重条 件とすることが実験実施上必要である. 実験ではジャッ キ荷重, ジャッキ変位，ケーソン変位，鋼杭ひずみ，杭 頭部のたわみを計測した。 また，土槽側面から写真撮影 を行い，地盤の変形挙動を観察した。

ここでの載荷実験では, 鋼杭の板厚と使用寸る本数を 変えることにより, 用いる杭の全体の曲げ岡性を変化さ 
せ，本補強工法に及ぼす鋼杭の曲げ岡性の影響について 検討した．表-2 に実験ケースの一覧を示す．なお，表中 のハイフンで結ばれた数字が実験ケース名を表している. なお，杭を 12 本，6本，3本用いたそれぞれのケースで の杭中心間隔は，それぞれ 33mm，60mm，120mm とし た.

\section{3. 実験結果}

(1) 杭の曲け剛性の違いによるケーソンの抵抗性の変化

図-3 に，杭本数は 12 本のまま，杭の曲げ岡性を変え たケースについてケーソンに作用する荷重とケーソンの 中心変位の関係を示す. 図-3より, 杭の岡性が小さくな るとケーソンの抵抗が小さくなった. ただし, Case3-12 と Case1-12 では杭の曲げ岡性が 33 倍違うことを考慮す ると，杭の曲げ岡性の違いによるケーソンの抵抗性の変 化はわずかなものであることが分かる.

図-4 は同じ曲げ岡性(板厚 $3.2 \mathrm{~mm})$ を持つ杭の本数を変 えて実験した結果を示す．杭本数が少なくなるとケーソ ンの抵抗性が小さくなった. ただし，ケーソンの中心水 平変位が約 $40 \mathrm{~mm}$ に達するまでは，12 本用いた場合と 6 本用いた場合とで抵抗性にほとんど差がなかった。

一般に，鋼杭頭部に水平荷重を作用させると，杭岡性

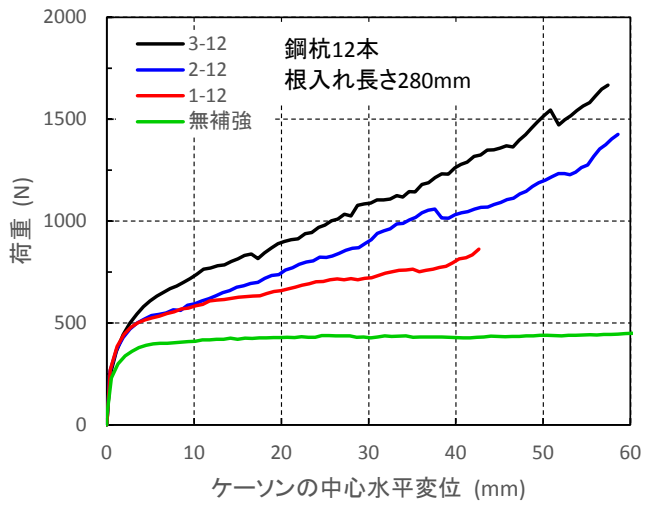

図-3鋼杭の曲げ岡性の違いによるケーソンの抵抗性の違い

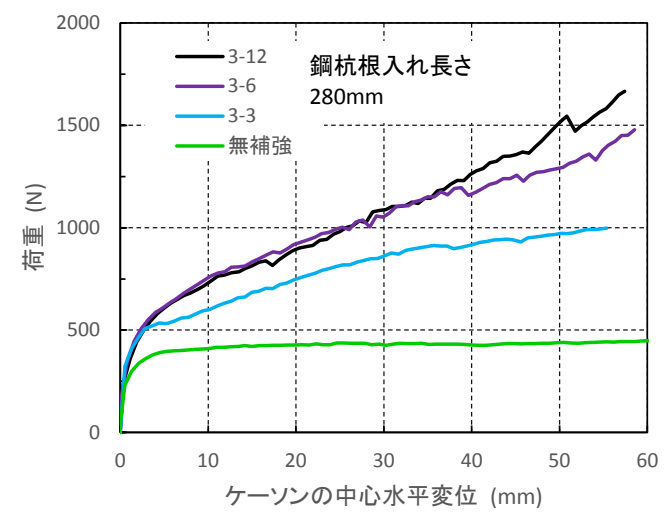

図-4＼cjkstart鋼杭間隔の違いによるケーソンの抵抗性の違い
が高いほうが抵抗性が高くなるが，図-3 と図-4を見る限 り，杭の曲げ岡性の違いに比べてケーソンの抵抗性には あまり大きな違いがなかった。 そこで，さらに，杭間隔 を広げたケースについて，杭 1 本あたりの曲げ剛性が異 なる時のケーソンの抵抗性の変化についてみてみた。図 -5 は杭を 3 本使用した時の曲げ岡性の異なる実験の結果 を比較したものである。この結果では，曲げ剛性の違い の影響はほとんど見られない。同様に，鋼杭を 6 本用い た場合についても比較したが，杭の曲げ岡性の影響がケ ーソンの抵抗性に及ぼす影響はあまり見られなかった。

特に，曲げ岡性が高い，Case4-6 と Case5-3 が，それら より曲げ岡性が低いものを用いた場合よりもケーソンの 抵抗性が低い傾向にあった。

さらに，全体の杭の曲げ岡性が変わらない条件で杭本 数が異なる実験の結果を図-6に示す。この結果を見ると, 全体の杭の曲げ岡性が等しい場合でも，杭の本数が異な ることによって,ケーソンの抵抗性が変化した.つまり， この結果によると杭本数が少なくなるほどケーソンの抵 抗性が低下する結果となった.

そこで, Case3-12, Case4-6, Case5-3 のケースについて, ケーソンに作用する荷重が比較的大きな $950 \mathrm{~N}$ の時のケ

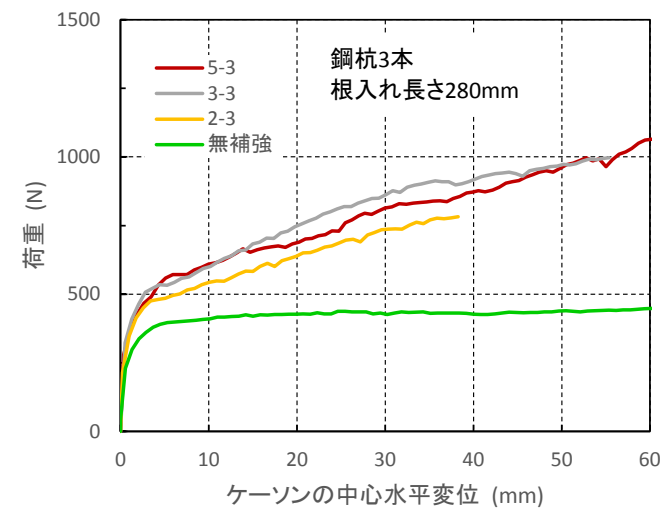

図-5 鋼杭を 3 本用いた場合の杭の曲げ岡性の違いによるケー ソンの抵抗性の違い

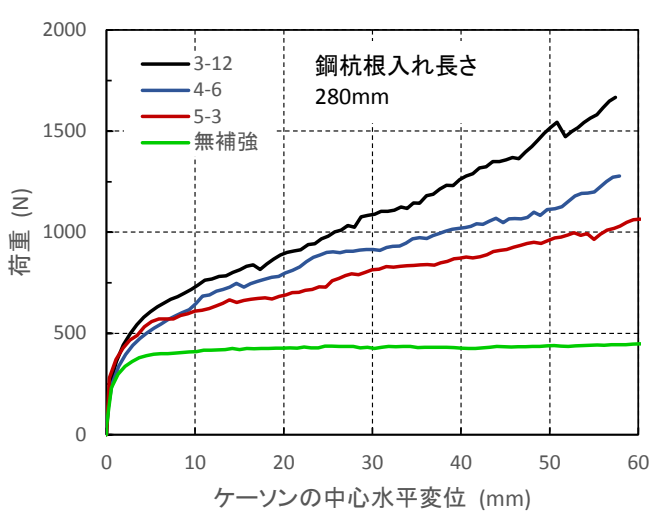

図-6 単位奥行長さあたりの鋼杭曲げ岡性が等しい時のケーソ ンの抵抗性 
ーソンの挙動を確認したのが，図-7である.

図-3〜図-6 では，ケーソンの中心変位をもとにケーソ ンの抵抗性を確認していたが，図-7では，ケーソンがあ る程度大きく変位したケーソン中心変位が $30 \mathrm{~mm}$ の時の それぞれの実験条件におけるケーソンの挙動を比較した. この結果を見ると, 杭本数が少ないほうが, 回転も大き いことが分かる．このことは，ケーソンの下端の杭側端 部の水平変位の違いはケーソン中心水平変位の違いより は小さくなっていることを意味している.

なお，ケーソンの中心水平変位が $30 \mathrm{~mm}$ と等しい時の ケーソンの変位挙動を見ると, 杭間隔の違いによる影響 はほとんど見られなかった.ただし，この時の杭の地表 面変位を見ると, 杭本数によって多少の違いがあった.

以上の結果は, Case4-6 と Case5-3 ではややケーソン の抵抗性が低いことを意味している. そこで，杭の挙動 にどのような違いがあるか検討した. ケーソンに作用し た水平荷重が 950N のところで，図-6 に示したケースで 杭に生じている曲げモーメント分布を比較したのが図-8 a)である. 図-8 に示す○印の点のうち杭上端と下端を除 いたものが曲げモーメントを測定した深度である。この 図にあるように，杭の本数が減るにつれて 1 本の杭が受 け

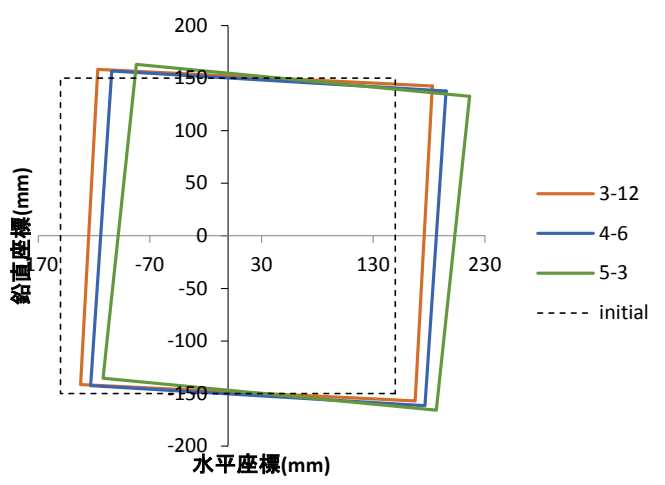

図-7 ケーソン作用荷重が 950N の時のケーソンの変位

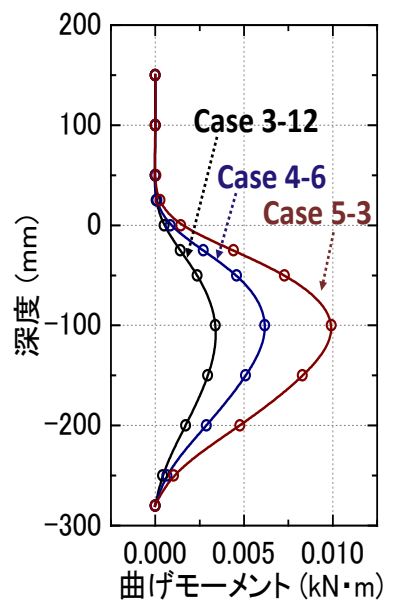

a) 曲げモーメント分布

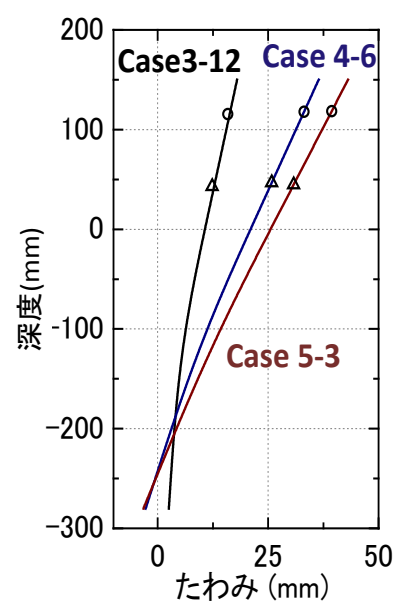

b) たわみ分布
図-8 ケーソン作用荷重が 950N の時の鋼杭の挙動

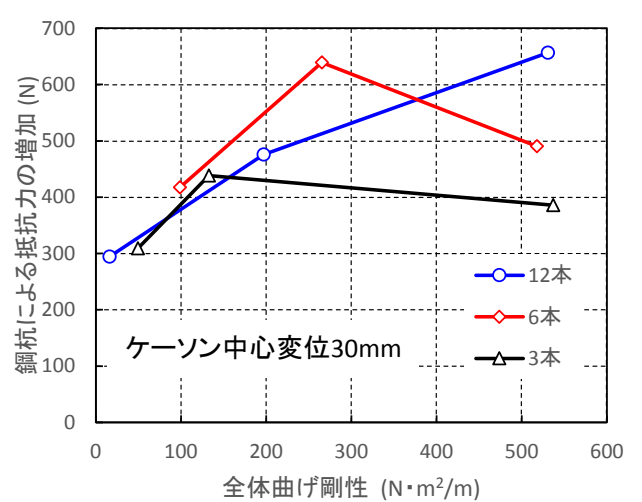

図-9 全体曲げ岡性の違いがケーソンの抵抗性に及ぼす影響

持つ荷重に違いが生じるため, 杭本数が少ないほど大き な最大曲げモーメントが生じることになる．この測定結 果を杭頭での変位とたわみ角を境界条件として二階積分 して, 杭のたわみ分布を調べると図-8b)のようになった. ここで○と $\triangle$ は図-2 に示したレーザー変位計の測定に よる変位の実測值である.このように，これらのケース の中では，Case4-6 と Case 5-3 の場合に，根入れ不足が 生じ杭が倒れこむような状態となっていた. すなわち,

Case4-6 と Case 5-3 では, 杭の岡性が高いことと, 杭 1 本あたりに作用する荷重が大きくなることが理由で，杭 の根入れが不足して相対的に，ケーソンの変位が大きく なる傾向となったものと考えられる.

そこで, 図-9に, 表-2に示したすべての実験に基づき， ケーソンの中心水平変位が $30 \mathrm{~mm}$ の時の杭の全体曲げ岡 性と鋼杭を用いることによるケーソンの抵抗力の増加分 との関係を示した. なお，鋼杭によるケーソンの抵抗力 の増分は，鋼杭を用いた場合のケーソンに作用した荷重 から，同じケーソン中心水平変位の時の無補強の場合の ケーソンの抵抗力を差し引いて求めたものである. 杭の 挙動を見ると図-9 に示した全体曲げ岡性が約 $500 \mathrm{Nm}^{2} / \mathrm{m}$ で杭本数が 6 本と 3 本の場合を除き, 杭の根入れが明ら かに短いという条件のものはなかった.

図-9 の結果からは，杭の曲げ岡性が比較的小さい場合 には，杭本数によらず，杭の全体曲げ剛性でケーソンの 抵抗性が決まる傾向にあるが，杭の曲げ岡性が高い場合 に，杭本数が少なくなるとケーソンの抵抗性が相対的に 小さくなる傾向があることが分かる．また，この時，こ れらの杭では杭下端の固定状態が低く, 杭が倒れこむよ うな挙動をしていた. このことからすると, 杭の根入れ 不足が生じない限り，本補強工法における補強効果は杭 本数にはあまりよらず，全体曲げ岡性の影響を強く受け るのではないかと考えられる。 また，その一方で，曲げ 岡性の違いによるケーソンの抵抗性の違いが比較的小さ いことも特徴的である.

今後は, 鋼杭 1 本あたりの剛性が大きい場合，「十分な 
根入れ長」とはどういうことなのかということを議論し ていく必要がある.

\section{（2）杭の曲げ剛性の違いによる杭に作用する荷重の変化}

これまでに見てきた結果は，杭の岡性の違いによるケ ーソンの抵抗性の違いが比較的小さいということであっ た.また, 杭の杭頭部分に水平力を作用させた場合には, 杭頭に単位曲げ岡性当たり同じ荷重が作用した場合の地 表面変位は杭の曲げ岡性が高いほうが大きくなる傾向に ある．その意味で，杭頭付近に杭の曲げ岡性が異なって いても杭頭付近に同じ条件で荷重が作用しているとすれ ば，図-9 のように全体曲げ岡性が等しければ抵抗性が同 じであるということにはならないことになる.これらの ことは，実際には，杭の曲げ剛性が異なれば，杭 1 本が 受け持つ荷重の分布が異なっていることを意味するもの と思われる。

この違いについて検討寸るため, 杭の岡性が異なる場 合に，ケーソン側から杭に作用する荷重分布がじのよう になっていたかについて検討する。ここでは, Case 1-12, 2-12, 3-12 の結果を比較して検討寸る.

図-10 にこれらのケースの曲げモーメント分布とそれ を二階積分したたわみ分布とを示寸，さらに，図-10a) に示した曲げモーメントを二階微分することにより，杭 が受けている地盤反力分布を求め, 図-11 に示した. こ の結果によると，杭は，中詰め部分から地表面付近にか けてケーソン側から強く押されていることが分かる。ま た，杭のたわみモードの違いを反映してか，杭の曲げ岡 性が異なることにより, 地盤反力分布に違いが出ている.

図-11 に示した地盤反力分布は，杭に作用する曲げモ 一メント分布から求めたものであるため, 杭の両側から 作用している地盤反力の差分を示している. ケーソン側 から杭に作用している荷重を推定するためには，杭のた わみによる地盤反力を差し引くことが必要である。ここ では，杭がたわんだことによる地盤反力は港研方式の $\mathrm{S}$ 型地盤モデル5)用いて推定した. $\mathrm{S}$ 型地盤モデルは $p=$

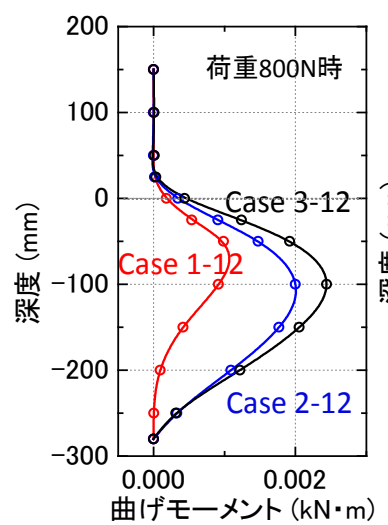

a) 曲げモーメント分布

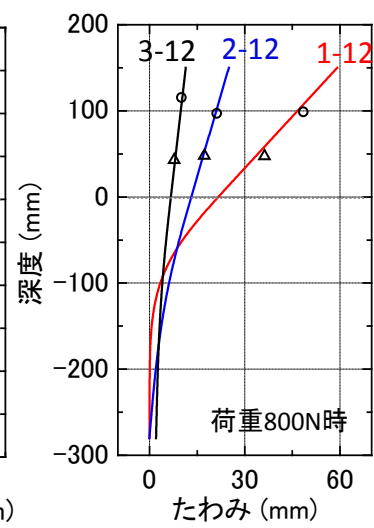

b) たわみ分布
図-10 ケーソン作用荷重 800N 時の鋼杭の挙動 $k_{\mathrm{s}} \cdot x \cdot y^{0.5}$ であらわされる. ただし, $k_{\mathrm{s}}$ : 地盤反力係数 $\left(\mathrm{kN} / \mathrm{m}^{3.5}\right), x$ : 深度 $(\mathrm{m}), y$ : 深さ $x$ における鋼杭のたわみ $(\mathrm{m}), p$ : 深さ $x$ における単位幅あたりの地盤反力 $\left(\mathrm{kN} / \mathrm{m}^{2}\right)$ である。

なお，この地盤の地盤反力係数 $k_{\mathrm{s}}$ は，実際に模型地盤 において単杭の載荷試験を実施し，杭頭荷重と杭頭変位 の関係から推定した. なお, $k_{\mathrm{s}}=2370 \mathrm{kN} / \mathrm{m}^{3.5}$ であるとした。

図-12 に杭のたわみに基づく地盤反力分布を示寸.

図-11 に示した地盤反力から図-12 に示した地盤反力 を引くことにより，ケーソン側から杭に作用している荷 重分布を推定したのが，図-13 である。二階微分の限界 と港研方式の限界から図-13では深度 150mm より下は精 度が十分にはないと考えられるが，この図を見ると，杭 には主として裹込めを介して荷重が杭に作用しているこ と，地中の比較的浅い個所では，杭には荷重があまり作 用しない傾向にあることがわかる。このような傾向は森 安ら ${ }^{6}$ の数值解析結果からも見られた傾向である. また, 杭の曲け剛性が異なることによって作用する荷重分布に も違いがみられる。それは，杭の曲げ岡性が高いほど地 盤面より上方で荷重が伝達し，杭の曲げ岡性が小さくな るとより深い部分で荷重が伝達するようになるという違 いである.これは杭のたわみのモードの影響を受けたも のであると考えられる.

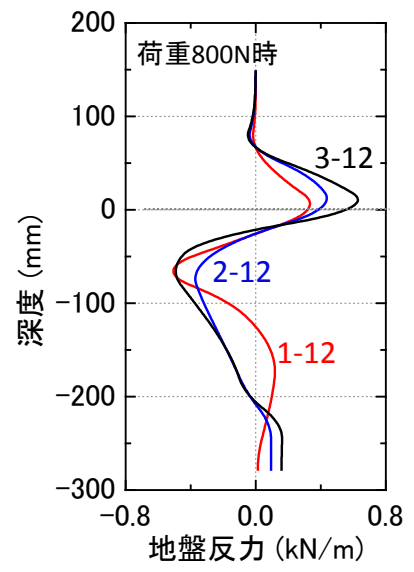

図-11＼cjkstart地艋反力分布(曲げモーメントの二階積分)

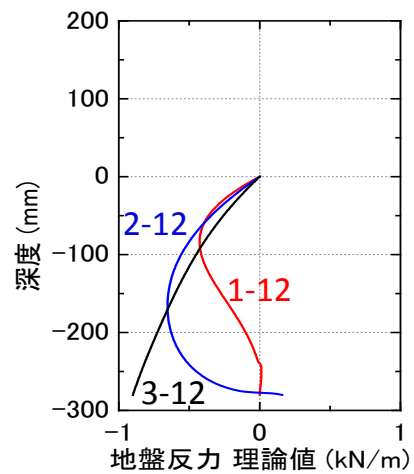

図-12 たわみ分布から港研方式により推定されるケーソン反 対側に作用寸る地艋反力分布 


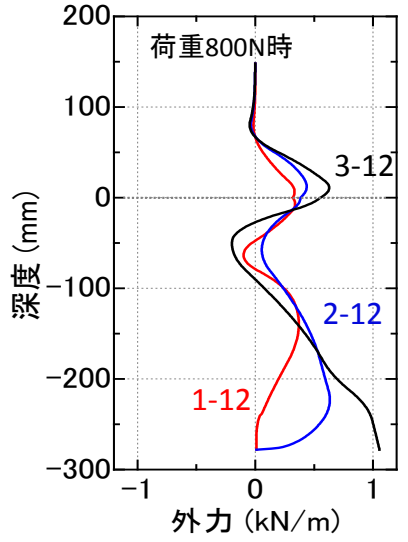

図-13 ケーソン側から杭に作用していると推定される荷重の 分布

以上のように，図-13 の結果からもわかる通り，杭の 曲げ剛性が小さいほうがより低い位置にケーソン側から の荷重が作用する傾向にあるため，杭の曲げ岡性が比較 的小さい場合でもケーソンの抵抗性が向上しや寸い傾向 にあると考えられる。

\section{4. 結論}

本稿では，津波対策を前提とした防波堤の鋼杭による 補強工法における，鋼杭の曲げ岡性の違いが本工法の補 強効果に及ぼす影響を, 模型気中水平載荷試験を行うこ とにより検証した。 その結果を以下にまとめる.

ケーソンの抵抗性は, 鋼杭の本数によらず, ケーソン 背後に根入れした鋼杭全体曲げ岡性で決まることがわか った. ただし，杭の全体曲げ岡性の違いによるケーソン の抵抗性の変化は比較的小さいことがわかった。

ケーソンから杭に作用する荷重を評価したところ，図 -13に示すように鋼杭は，地表面近くではケーソン側か
ら大きな荷重を受け，それより深い部分ではケーソン側 から小さな荷重を受けていることが分かった．また，裏 込めから地表面にかけてのケーソン側から杭に作用する 荷重分布は杭の岡性が異なることによって変化すること が分かった．このように，杭の曲け剛性が低いほうが地 表面付近の杭に作用する荷重が小さくなることが理由で， 杭の曲げ岡性の違いによるケーソンの抵抗性の変化が小 さくなったものと考えられる.

謝辞 : 本研究の実行にあたり，妙中真治様(新日鐵住金株 式会社)に多大なご協力をいただきました.ここに記して， 深謝いたします.

\section{参考文献}

1) Yoshiaki Kikuchi, Shohei Kawabe, Shinji Taenaka, Shunsuke Moriyasu : Horizontal loading experiments on reinforced gravity type breakwater with steel walls, Japanese Geotechnical Society Special Publication, Vol. 2, No. 35 pp. 1267-1272, 2015.

2）有川太郎，及川森，森安俊介，岡田克寛，水谷崇亮，菊池 喜昭，八尋明彦，下迫健一郎：鋼杭による防波堤補強工法 の越流時における安定性に関寸る研究，港湾空港技術研究 所資料 No.1298，2015.

3）勝呂基弘, 菊池喜昭, 兵動太一, 喜古真次, 長澤宗一郎, 森安俊介，及川森 : 鋼杭による防波堤補強工法に関する模 型気中載荷実験, 土木学会論文集 B4(海洋開発) Vol.71(2015)No.2 p.I_617-I_622, 2015.

4) 井合進 : $1 \mathrm{~g}$ 場での地盤 - 構造物 - 流体系の模型振動実験 の相似則，港湾技術研究所報告，Vol.27，No.3，pp.3-24， 1988.

5) 久保浩一: 杭の横抵抗の新しい計算法, 港湾技術研究 所報告 第 2 巻 3 号 Vol.2 No.3,1964

6) 森安 俊介, 菊池 喜昭, 田中 隆太, 妙中 真治: 鋼杭による 防波堤補強工法の抵抗機構に関寸る数值解析, 土木学会論 文集 B3, Vol. 71, No. 2, p. I_611-I_616, 2015.

(2016.2.4 受付)

\section{EFFECT OF FLEXURAL RIGIDITY OF PILES ON HORIZONTAL RESISTANCE OF REINFOCED GRAVITY TYPE BREAKEWATER WITH STEEL PIPE PILES}

\section{Motohiro SUGURO, Yoshiaki KIKUCHI, Taichi HYODO, Yutaro YAMAZAKI, Sayako TAMAKI, Shunsuke MORIYASU and Shin OIKAWA}

In The 2011 off the Pacific coast of Tohoku Earthquake, coastal area breakwaters of the Pacific Ocean were suffered extensive damage by tsunami attacks. A method for reinforcing an existing caisson type breakwater against tsunami attacks with a steel pipe piles behind the breakwater and filling rubbles between breakwater and piles were proposed. Horizontal loading experiments on model breakwaters were conducted on dry sand condition to develop a design verification method on steel piles used in this reinforcing method. Flexural rigidity of a pile and number of piles used in an experiment were changed. Resistance increment of the caisson was mostly affected by total flexural rigidity of piles in a unit length along breakwater length. The paper also discussed force acting on piles from the caisson side. Clarifying the distribution and intensity of the force acting on the pile can make an effective design verification method of piles to be used in this reinforcement. 